\title{
KEEFEKTIVAN INTEGRASI SINTAKS INKUIRI TERBIMBING DAN STAD (INSTAD) UNTUK MEMPERKECIL KESENJANGAN KETERAMPILAN METAKOGNISI SISWA AKADEMIK ATAS DAN BAWAH
}

\author{
Baskoro Adi Prayitno \\ Universitas Sebelas Maret Surakarta \\ baskoro_ap@fkip.uns.ac.id \\ Bowo Sugiharto \\ Universitas Sebelas Maret Surakarta \\ bowo@fkip.uns.ac.id
}

\begin{abstract}
This study aimed at investigating the influence of INSTAD model compared to guided inquiry, STAD and conventional toward metacognition skill, the influence of academic achievement toward metacognition skill, and interaction of learning model and academic achievement toward metacognition skill. The method used in this study is a quasi-experimental research method with factorial design of $2 x 4$. The population of this study is seventh grade students of all State Junior High School in Surakarta. The writers used random sampling technique with school criteria of high and low quality. The research findings showed that there is an influence on learning model of metacognition skill. INSTAD model and guided inquiry are not significantly different, but those are significantly different from the Conventional and STAD models toward metacognition skill. There is an influence on the academic achievement toward metacognition skill. Upper academic students have higher metacognition skill than lower academic students do. There is interaction of learning model and academic achievement toward metacognition skill.
\end{abstract}

Keywords: Inquiry, STAD, INSTAD, Metacognition, Academic achievement

\begin{abstract}
Abstrak
Penelitian ini bertujuan menguji pengarub integrasi sintaks model pembelajaran inkuiri terbimbing dan STAD (INSTAD) dibandingkan inkuiri terbimbing, STAD, dan konvensional terhadap keterampilan metakognisi, Pengarub kemampuan akademik terhadap keterampilan metakognisi, Interaksi model pembelajaran dan kemampuan akademik terhadap keterampilan metakognisi. Metode penelitian menggunakan kuasi eksperimen dengan desain faktorial 4x2. Populasi penelitian adalab siswa kelas VII SMPN se Surakarta. Teknik sampling menggunakan stratifield random sampling dengan kriteria mutu sekolah atas dan bawah. Temuan penelitian, ada pengarub model pembelajaran terhadap keterampilan metakognisi. Model INSTAD dan inkuiri terbimbing tidak berbeda nyata namun berbeda nyata dengan model STAD dan konvensional terhadap keterampilan metakognisi. Ada pengarub kemampuan akademik terbadap keterampilan metakognisi siswa. Siswa akademik atas (AA) memiliki keterampilan metakognisi lebih tinggi dibanding siswa akademik bawah ( $A B)$. Ada interasi antara model pembelajaran dan kemampuan akademik terhadap keterampilan metakognisi.
\end{abstract}

Kata Kunci: Inkuiri, STAD, INSTAD, Metakognisi, Kemampuan Akademik

Permalink/DOI: http://dx.doi.org/10.18326/infs13.v9i2.305-328 


\section{Pendahuluan}

Dunia telah memasuki era informasi. Salah satu kata kunci kesuksesan sesorang di era informasi adalah dikuasainya keterampilan metakognisi. Keterampilan metakognisi merupakan pendorong munculnya inisiatif untuk menjadikan seseorang menjadi pebelajar mandiri. Arus pengetahuan di era informasi berjalan sangat cepat, untuk konteks pendidikan mengandalkan informasi hanya dari sekolah menjadi kurang relevan. Oleh karena itu, siswa perlu dibekali kemampuan menjadi pebelajar mandiri untuk sukses di era informasi, salah satunya perlu dibekali keterampilan metakognisi. Keterampilan metakognisi berkorelasi kuat dengan keberhasilan belajar siswa. Susantini (2004) menyatakan keterampilan metakognisi mampu membuat siswa menjadi pebelajar mandiri, jujur, berani mengakui kesalahan, dan dapat meningkatkan prestasi belajarnya. Imel (2002) menyatakan keterampilan metakognisi mempengaruhi keberhasilan belajar siswa. Peters (2006) melaporkan siswa yang terampil metakognisi cenderung lebih kompeten dibandingkan siswa yang kurang terampil metakognisi.

Sementara itu, berbagai kajian terhadap penguasaan keterampilan metakognisi siswa di Indonesia memprihatinkan. Kajian Nurmaliah, 2009 di Malang; Suratno, 2009 di Jember; dan Paidi, 2008 di Yogjakarta menunjukkan keterampilan metakognisi siswa dalam kategori belum berkembang. Kajian Prayitno (2010) di Kota Surakarta menunjukkan 92,6\% guru tidak memahami konsep metakognisi, sehingga patut diduga pelatihan keterampilan metakognisi oleh guru tidak dirancang dan dikelola dengan sengaja. Cao dan Nietfeld (2007) menyatakan keterampilan metakognisi tidak hadir tiba-tiba dalam pembelajaran. Pelatihan keterampilan metakognisi harus dirancang dan dikelola dengan sengaja, terencana, dan berkelanjutan oleh guru.

Permasalahan lain yang mendesak untuk segera diselesaikan adalah usaha memperkecil kesenjangan keterampilan metakognisi antara siswa akademik bawah (AB) dengan siswa akademik atas (AA). Menurut Nasution (2000) kemampuan akademik siswa terklasifikasi menjadi akademik atas dan bawah. Variasi kemampuan akademik disebabkan oleh tidak selalu liniernya hubungan antara kecerdasan 
dengan usia seseorang. Kecerdasan seseorang mungkin lebih tinggi, lebih rendah, atau sama dengan usianya (Ousena dan Laurie, 2007). Sebagian besar orang meyakini, siswa berkemampuan AB selamanya memiliki keterampilan metakognisi yang rendah. Caroll (1965) dalam (Ozden, 2008) menyatakan, prestasi belajar termasuk keterampilan metakognisi tidak hanya ditentukan oleh kemampuan akademik. Prestasi belajar termasuk keterampilan metakognisi lebih banyak dipengaruhi oleh alokasi waktu yang diberikan kepada siswa untuk belajar. Siswa AB dapat sejajar prestasi belajar termasuk keterampilan metakognisinya dengan siswa AA, jika siswa AB diberikan waktu belajar yang mencukupi. Di sisi lain, alokasi waktu belajar di sekolah uniform bagi semua siswa. Model pembelajaran yang tepat diperlukan untuk mengangkat keterampilan metakognisi siswa AB agar mencapai taraf mastery layaknya siswa berkemampuan AA.

Keterampilan metakognisi dapat dilatihkan melalui pembelajaran berbasis konstruktivis. Menurut Peters (2006) terdapat hubungan kuat antara keterampilan metakognisi dengan aktivitas pembelajaran berbasis konstruktivis. Pembelajaran berbasis konstruktivis dapat meningkatkan keterampilan metakognisi, karena pembelajaran berbasis konstruktivis menuntut siswa mengkonstruksi sendiri pengetahuan. Kegiatan mengkonstruksi sendiri pengetahuan mengantarkan siswa mengetahui posisi kognisinya ketika mereka membangun pengetahuan, akibatnya keterampilan metakognisi siswa dapat terlatihkan melalui kegiatan refleksi diri, merencanakan kembali, memantau ulang, dan mengevaluasi kembali hasil belajarnya.

Usaha memperkecil kesenjangan keterampilan metakognisi antara siswa $\mathrm{AA}$ dan $\mathrm{AB}$ dapat diatasi dengan menggunakan model pembelajaran berbasis kooperatif. Model pembelajaran berbasis kooperatif memungkinkan proses scaffolding oleh siswa AA dan guru menjadi lebih optimal. Proses scaffolding yang optimal akan mengantarkan siswa AB memasuki zona perkembangan proksimalnya tanpa harus terikat pada waktu yang uniform di kelas. Hal ini sejalan dengan studi Corebima (2007) terhadap skripsi, tesis, dan disertasi di Universitas Negeri Malang yang menunjukkan pembelajaran kooperatif dapat memperkecil kesenjangan prestasi belajar dan 
keterampilan metakognisi siswa $\mathrm{AA}$ dan $\mathrm{AB}$, karena aktifitas diskusi kelompok dalam pembelajaran kooperatif mampu memfasilitasi kegiatan saling membelajarkan antar siswa (Slavin, 2005). Kegiatan saling membelajarkan memberikan waktu belajar yang cukup bagi siswa AB melalui scaffolding pada siswa AA, sehingga kesenjangan keterampilan metakognisi siswa dapat diperkecil.

Model INSTAD dikembangkan oleh Prayitno (2010) untuk meningkatkan keterampilan metakognisi sekaligus memperkecil kesenjangannya antara siswa AA dan AB. INSTAD merupakan hasil integrasi sintaks model inkuiri terbimbing dan STAD. INSTAD memiliki karakter inkuiri dan STAD. Karakter inkuiri sebagai strategi kognitif mampu melatihkan keterampilan metakognisi dengan baik. Livingston (2005) menyatakan terdapat hubungan antara strategi kognitif dengan keterampilan metakognisi. Model inkuiri terbimbing mampu melatih kemampuan mengelola diri pada siswa (Peters, 2006). Kemampuan mengelola diri merupakan bagian dari keterampilan metakognisi. Karakter STAD pada INSTAD mampu melatihkan keterampilan metakognisi melalui aktivitas diskusi dan pelatihan berpikir. INSTAD memfasilitasi kegiatan saling membelajarkan antar siswa. Siswa berkemampuan AA yang telah menguasai keterampilan metakognisi memberikan scaffolding kepada siswa $\mathrm{AB}$ yang belum menguasai keterampilan metakognisi. Scaffolding berpotensi mendorong siswa berkemampuan $\mathrm{AB}$ memasuki zona perkembangan proksimalnya. Tutorial sebaya pada INSTAD memberikan waktu belajar yang mencukupi bagi siswa $\mathrm{AB}$, sehingga mereka mampu mencapai taraf mastery sebagaimana siswa AA.

Berdasarkan latar belakang masalah di atas, dapat dirumuskan masalah sebagai berikut: 1) Bagaimanakah pengaruh integrasi sintaks model inkuiri terbimbing dan STAD (INSTAD) dibandingkan model inkuiri terbimbing, STAD, dan konvensional terhadap keterampilan metakognisi?. 2). Bagaimanakah pengaruh kemampuan akademik terhadap keterampilan metakognisi? 3) Apakah ada interaksi antara model pembelajaran dan kemampuan akademik terhadap keterampilan metakognisi? 


\section{Model Pembelajaran INSTAD}

INSTAD adalah model pembelajaran hasil intergrasi sintaks model pembelajaran inkuiri terbimbing dan STAD. Filosofi yang melandasi pengintegrasian sintaks adalah pembelajaran akan lebih bermakna bila siswa bekerja menemukan pengetahuan melalui kegiatan inkuiri di dalam kerja kooperatif. Pengetahuan merupakan hasil inkuiri ilmuwan dalam menemukan ilmu. Ilmuwan pada kerja inkuirinya tidak pernah bekerja sendiri. Ilmuwan selalu bekerja dalam team work yang saling membantu dan mendukung. Filosofi tersebut perlu dilatihkan pada siswa yang sedang belajar menemukan ilmu. Kegiatan inkuiri yang dilaksanakan pada kerja kooperatif merupakan wujud pragmatis penerapan filosofi tersebut di dalam kelas (Prayitno, 2010).

Sintaks model INSTAD dikembangkan dengan prosedur sebagai berikut. Fase sintaks model inkuiri terbimbing diintegrasikan pada fase kerja kelompok model STAD. Fase pengulangan pada model inkuiri terbimbing digunakan untuk memperkuat sintaks model STAD. Fase pengulangan ditempatkan sebelum fase kuis individu dan fase penghargaan kelompok pada sintaks model STAD. Sintaks model INSTAD sebagai berikut. (1) Fase I penjelasan guru. (2) Fase II kerja inkuiri dalam kelompok kooperatif. (3) Fase III pengulangan. (4) Fase IV tes individu. (5) Fase V rekognisi kelompok (Prayitno, 2010). Sintaks model INSTAD divisualisasikan pada Tabel 1.

Model INSTAD mempunyai karakter STAD yang terbukti mampu memperkecil kesenjangan prestasi belajar antara siswa AA dan AB. Karakter STAD mampu memfasilitasi proses scaffolding. Scaffolding siswa AA kepada siswa AB terbukti mampu mengantarkan siswa $\mathrm{AB}$ memasuki zona perkembangan proksimalnya, sehingga prestasi belajar siswa $\mathrm{AB}$ dapat sejajar dengan siswa AA. Tutorial siswa AA kepada siswa AB terbukti mampu memberikan waktu belajar yang mencukupi bagi siswa $\mathrm{AB}$, sehingga siswa $\mathrm{AB}$ mampu mencapai taraf mastery seperti halnya siswa AA. 
Tabel 1.

Sintaks Model INSTAD

\begin{tabular}{|c|c|c|}
\hline Tahapan & Kegiatan Guru & Kegiatan Siswa \\
\hline $\begin{array}{l}\text { Orientasi } \\
\text { Masalah }\end{array}$ & $\begin{array}{l}\text { Guru membentuk } \\
\text { kelompok kooperatif } \\
\text { (3-4 siswa) heterogen. } \\
\text { Guru menyajikan } \\
\text { masalah inkuiri. }\end{array}$ & $\begin{array}{l}\text { Siswa membagi diri } \\
\text { dalam kelompok } \\
\text { kooperatif yang telah } \\
\text { dibentuk. }\end{array}$ \\
\hline \multirow[t]{5}{*}{$\begin{array}{l}\text { Kerja inkuiri } \\
\text { dalam } \\
\text { kelompok } \\
\text { kooperatif }\end{array}$} & $\begin{array}{l}\text { Guru membimbing } \\
\text { siswa menemukan dan } \\
\text { merumuskan masalah. }\end{array}$ & $\begin{array}{l}\text { Siswa menemukan dan } \\
\text { merumuskan masalah. } \\
\text { Siswa merumuskan }\end{array}$ \\
\hline & $\begin{array}{l}\text { Guru membimbing } \\
\text { siswa merumuskan } \\
\text { hipotesis. }\end{array}$ & $\begin{array}{l}\text { hipotesis. } \\
\text { Siswa merancang } \\
\text { eksperimen untuk }\end{array}$ \\
\hline & $\begin{array}{l}\text { Guru memfasilitasi } \\
\text { siswa merancang } \\
\text { eksperimen untuk } \\
\text { mengumpulkan data. }\end{array}$ & $\begin{array}{l}\text { mengumpulkan data. } \\
\text { Siswa menganalisis } \\
\text { data dan menguji } \\
\text { hipotesis. }\end{array}$ \\
\hline & $\begin{array}{l}\text { Guru membimbing } \\
\text { siswa menganalisis data } \\
\text { dan menguji hipotesis. }\end{array}$ & $\begin{array}{l}\text { Siswa membuat } \\
\text { simpulan. }\end{array}$ \\
\hline & $\begin{array}{l}\text { Guru membimbing } \\
\text { siswa menyimpulkan }\end{array}$ & \\
\hline $\begin{array}{l}\text { Presentasi } \\
\text { Kelas }\end{array}$ & $\begin{array}{l}\text { Guru meminta } \\
\text { kelompok untuk } \\
\text { mempresentasikan } \\
\text { hasil kerja kelompok di } \\
\text { depan kelas. }\end{array}$ & $\begin{array}{l}\text { Anggota kelompok } \\
\text { mempresentasikan } \\
\text { hasil kerja kelompok } \\
\text { di depan kelas. }\end{array}$ \\
\hline Tes individu & $\begin{array}{l}\text { Guru mengadakan tes } \\
\text { individual. }\end{array}$ & $\begin{array}{l}\text { Siswa mengerjakan tes } \\
\text { secara individual. }\end{array}$ \\
\hline Rekognisi Tim & $\begin{array}{l}\text { Guru memberikan } \\
\text { penghargaan pada } \\
\text { kelompok. }\end{array}$ & $\begin{array}{l}\text { Kelompok siswa yang } \\
\text { mencapai mendapatkan } \\
\text { penghargaan. }\end{array}$ \\
\hline
\end{tabular}


Model INSTAD mempunyai tiga keunggulan. Keunggulan pertama, model INSTAD mampu memperkecil kesenjangan prestasi belajar siswa berkemampuan AA dan AB. Keunggulan tersebut kurang dimiliki oleh inkuiri terbimbing dan konvensional. Keunggulan kedua, model INSTAD mampu melatihkan keterampilan proses sains dengan efektif. Keunggulan tersebut kurang dimiliki oleh STAD dan konvensional. Keunggulan ketiga, INSTAD menunjukkan potensi maksimal dalam melatihkan keterampilan metakognisi pada siswa berkemampuan AA maupun $\mathrm{AB}$

\section{Keterampilan Metakognisi}

Istilah metakognisi pertama kali dikenalkan oleh Flavel pada tahun 1976. Definisi metakognisi sampai saat ini masih menjadi perdebatan di kalangan ahli psikologi, sehingga definisi metakognisi tidak selalu sama dalam bidang kajian. Definisi metakognisi yang sering digunakan adalah kesadaran berpikir seseorang tentang proses berpikirnya (Eggen dan Kauchak, 1996). Menurut Moore (2004) metakognisi merupakan bentuk kognisi atau proses berpikir tingkat tinggi yang melibatkan pengendalian aktivitas kognitif. Metakognisi adalah berpikir tentang berpikirnya sendiri atau kognisi seseorang tentang kognisinya sendiri (Peters, 2006)

Metakognisi terdiri dari beberapa komponen. Milles dan Flavel (2003) dalam (Livingston, 1997) mengemukakan, metakognisi terdiri dari pengetahuan tentang kognisi dan monitoring kognisi. Dasoete (2001) menyatakan, metakognisi meliputi, pengetahuan metakognisi, keterampilan metakognisi, dan kepercayaan metakognisi. Komponen metakognisi saat ini sering dibedakan menjadi pengetahuan metakognisi dan keterampilan metakognisi. Pengetahuan metakognisi berupa pengetahuan deklaratif, pengetahuan prosedural, dan pengetahuan kondisional seseorang pada saat menyelesaikan masalah. Keterampilan metakognisi merujuk kepada keterampilan memprediksi, merencanakan, memonitor, dan mengevaluasi kognisinya sendiri (Coutinho 2007).

Siswa dikatakan terampil metakognisi, jika mereka terampil merencanakan, memantau, dan mengevaluasi kognisinya. Indikator siswa terampil merencanakan yaitu, (1) siswa dapat menetapkan 
tujuan yang ingin dicapai, (2) siswa dapat merencanakan waktu yang akan digunakan untuk mencapai tujuan, (3) siswa dapat mempersiapkan pengetahuan awal untuk mencapai tujuan, dan (4) siswa dapat merencanakan dan memutuskan strategi kognitif untuk mencapai tujuan. Indikator siswa terampil memantau yaitu, (1) siswa dapat memantau tujuan yang ingin dicapai, (2) siswa dapat memantau waktu yang digunakan, (3) siswa dapat memantau kecukupan pengetahuan awal, dan (4) siswa dapat memantau pelaksanaan strategi kognitif. Indikator siswa terampil mengevaluasi yaitu, (1) siswa dapat mengevaluasi ketercapaian tujuan, (2) siswa dapat mengevaluasi penggunaan waktu, (3) siswa dapat mengevaluasi relevansi pengetahuan awal, dan (4) siswa dapat mengevaluasi efektifitas strategi kognitif yang digunakan (Macleod, 2004)

Metakognisi bermanfaat bagi kemandirian belajar siswa. Susilo (2009) menyatakan metakognisi menekankan pemantauan dan tanggung jawab diri siswa, sehingga siswa dapat mengatur dirinya untuk merencanakan, memantau, dan mengevaluasi tujuan pembelajarannya. Siswa yang terampil metakognisi dipastikan menjadi pebelajar mandiri. Siswa yang terampil metakognisi dipastikan menjadi pebelajar mandiri. Susantini (2004) menyatakan kemampuan metakognisi mampu memberdayakan siswa menjadi pebelajar mandiri, jujur, berani mengakui kesalahan, dan dapat meningkatkan prestasi belajarnya. Imel (2002) menyatakan kemampuan metakognisi dapat mempengaruhi keberhasilan belajar siswa. Peters (2006) melaporkan siswa yang terampil metakognisi cenderung lebih kompeten dibandingkan dengan siswa yang kurang terampil metakognisi.

\section{Metode Penelitian}

Penelitian ini menggunakan kuasi eksperimen pretest-postest non equivalent control group design (Drew, 2008) Guna mengeleminasi variasi pada subjek penelitian, skor pretes dijadikan kovariat. Rancangan penelitian terdapat pada Gambar 1. Populasi penelitian adalah seluruh siswa kelas VII pada 27 SMP Negeri di Surakarta. Penarikan sampel menggunakan teknik stratifield random sampling dengan kriteria strata kualitas sekolah atas dan bawah. Kualitas 
sekolah dilihat dari nilai rata-rata ujian nasional input siswa. Sampel penelitian terdiri dari siswa berkemampuan AA dan siswa berkemampuan AB. Jumlah sampel AA 68 siswa dan AB berjumlah 68 siswa. Total sampel 136 siswa. Kriteria pengelompokkan kemampuan akademik siswa berdasarkan nilai UAN pada saat siswa sekolah dasar. Sampel penelitian divisualisasikan pada Tabel 2.

\begin{tabular}{|c|c|c|c|}
\hline & & & san: \\
\hline & & & , \\
\hline & & & vah. \\
\hline & $2 Y$ & & \\
\hline & $\mathrm{X} 2 \mathrm{Y} 2$ & O9 & \\
\hline & X3Y1 & $\mathrm{O} 10$ & INST \\
\hline & $\mathrm{X} 3 \mathrm{Y} 2$ & O12 & del kony \\
\hline & $\mathrm{X} 4 \mathrm{Y} 1$ & O14 & $, 011, \mathrm{O} 13, \mathrm{O} 15=$ prete \\
\hline & $\mathrm{X} 4 \mathrm{Y} 2$ & O16 & $014016=$ poste \\
\hline
\end{tabular}

Gambar 1

Rancangan Penelitian

\section{Tabel 2}

\section{Sampel Penelitian}

\begin{tabular}{|c|c|c|c|c|c|c|}
\hline Sekolah & Kelas & $\Sigma$ Siswa & $\Sigma \mathrm{AA}$ & $\Sigma \mathrm{AB}$ & $\begin{array}{l}\text { Perlakuan } \\
\text { Model }\end{array}$ & Nilai UN SD \\
\hline $\begin{array}{l}\text { SMPN } 7 \\
\text { Surakarta }\end{array}$ & VII A & 36 & 17 & 0 & $\begin{array}{l}\text { inkuiri } \\
\text { terbimbing }\end{array}$ & $\begin{array}{l}\text { AA: } \\
26,15-27,40\end{array}$ \\
\hline $\begin{array}{l}\text { SMPN } 27 \\
\text { Surakarta }\end{array}$ & VII C & 36 & 0 & 17 & (34 siswa) & $\begin{array}{l}\text { AB: } \\
20,20-21,35\end{array}$ \\
\hline $\begin{array}{l}\text { SMPN } 19 \\
\text { Surakarta }\end{array}$ & VII A & 36 & 17 & 0 & STAD & $\begin{array}{l}\text { AA: } \\
25,95-27,25\end{array}$ \\
\hline $\begin{array}{l}\text { SMPN } 26 \\
\text { Surakarta }\end{array}$ & VII A & 37 & 0 & 17 & (34 siswa) & $\begin{array}{l}\mathrm{AB}: \\
19,20-21,00\end{array}$ \\
\hline $\begin{array}{l}\text { SMPN } 02 \\
\text { Surakarta }\end{array}$ & VII D & 36 & 17 & 0 & INSTAD & $\begin{array}{l}\text { AA: } \\
26,30-28,50\end{array}$ \\
\hline $\begin{array}{l}\text { SMPN } 17 \\
\text { Surakarta }\end{array}$ & VII D & 36 & 0 & 17 & (34 siswa) & $\begin{array}{l}\text { AB: } \\
20,00-22,40\end{array}$ \\
\hline
\end{tabular}




$\begin{array}{lcccccl}\text { SMPN 08 } & \text { VII D } & 36 & 17 & 0 & \text { konvensional } & \text { AA: } \\ \begin{array}{l}\text { Surakarta } \\ \text { SMPN 22 }\end{array} & \text { VII C } & 35 & 0 & 17 & & 25,70-28,00 \\ \begin{array}{l}\text { Surakarta } \\ \text { Jumlah }\end{array} & & & & & (34 \text { siswa) } & \begin{array}{l}\text { AB: } \\ 21,30-22,35\end{array} \\ & 288 & 68 & 68 & 136 \text { siswa } & \end{array}$

Instrumen untuk mengukur keterampilan metakognisi menggunakan rubrik metakognisi terintegrasi achievment test yang dikembangkan oleh Corebima (2009). Keterlaksanaan sintak model pembelajaran selama perlakukan dipantau menggunakan lembar observasi. Sebelum digunakan instrumen diuji validitas dan reliabilitasnya. Data dianalisis menggunakan anakova dengan skor pre test sebagai kovariat. Sebelum uji anakova dilakukan uji prasarat statistik parametrik berupa uji normalitas data menggunakan uji Kolmogorov smirnov dan homogenitas varian menggunakan uji Levene's. Signifikansi perbedaan rata-rata variabel menggunakan BNT. Penghitungan statistik pada taraf signifikansi 0,05 .

\section{Analisis}

Berdasarkan data pretes dan postes diketahui, rata-rata skor pretes keterampilan metakognisi dalam rentang 18.6-25.4. Rata-rata skor postes dalam rentang 46.7-76.4. Diagram rata-rata skor pretes dan rata-rata skor postes keterampilan metakognisi divisualisasikan pada Gambar 2.

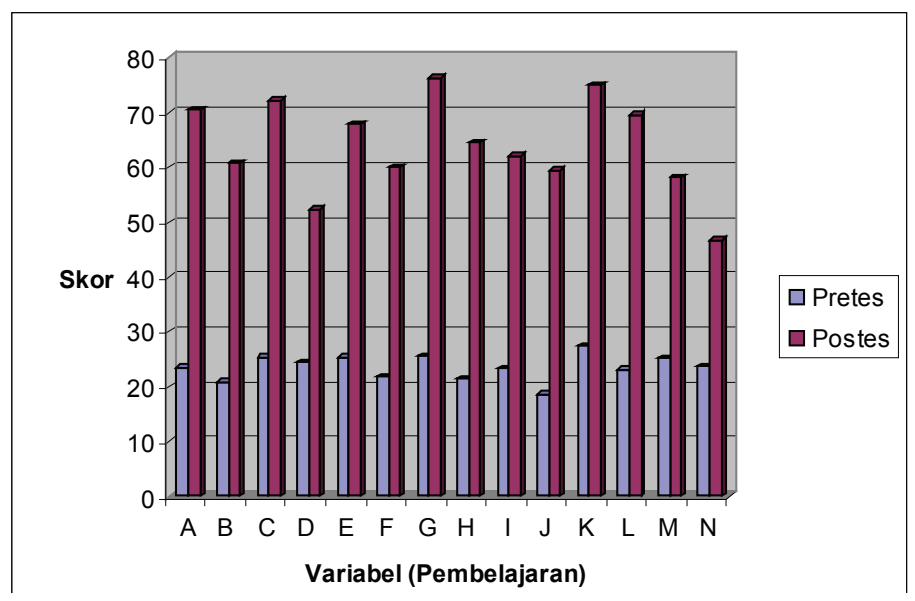




\section{Gambar 2 \\ Diagram Rata-Rata Skor Pretes dan \\ Postes Keterampilan Metakognisi}

Keterangan:

$\mathrm{A}=$ Inkuiri terbimbing

$\mathrm{B}=S T A D$

$\mathrm{C}=$ INSTAD

$\mathrm{D}=$ Konvensional

$\mathrm{E}=$ Kemampuan akademik atas

$\mathrm{F}=$ Kemampuan akademik bawah

$\mathrm{G}=$ Inkuiri terbimbing akademik atas

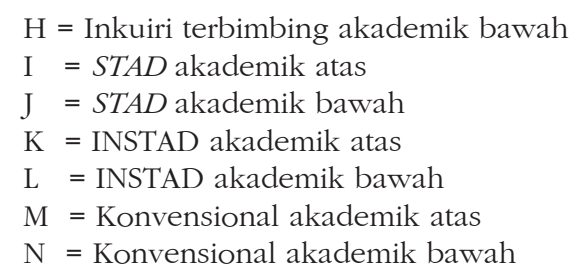

Pada kelompok model pembelajaran, rata-rata skor pretes keterampilan metakognisi berkisar antara 20,9-25,3. Rata-rata skor pretes kemampuan metakognisi sebesar 20,9 pada STAD. Rata-rata skor pretes kemampuan metakognisi sebesar 25,3 pada INSTAD. Rata-rata skor postes keterampilan metakognisi berkisar antara 52,4-72,2. Rata-rata skor postes keterampilan metakognisi sebesar 52,4 pada model konvensional. Rata-rata skor postes keterampilan metakognisi sebesar 72,2 pada model INSTAD. Pada kelompok kemampuan akademik, rata-rata skor pretes keterampilan metakognisi antara 21,7-25,4. Rata-rata skor keterampilan metakognisi sebesar 21,7 pada kemampuan $\mathrm{AB}$, sedangkan rata-rata skor keterampilan metakognisi sebesar 25,4 pada kemampuan AA. Rata-rata skor postes keterampilan metakognisi berkisar antara 60,1-67,9. Rata-rata skor postes keterampilan metakognisi sebesar 60,1 pada kemampuan AB. Rata-rata skor postes keterampilan metakognisi sebesar 67,9 pada kemampuan AA. Pada kelompok kombinasi model pembelajaran dengan kemampuan akademik, rata-rata skor pretes keterampilan metakognisi berkisar antara 18,6-27,4. Rata-rata skor pretes keterampilan metakognisi sebesar 18,6 pada STAD AB. Rata-rata skor pretes keterampilan metakognisi sebesar 27,4 pada model INSTAD AA. Rata-rata skor postes keterampilan metakognisi berkisar antara 46,7-76,4. Rata-rata skor postes keterampilan metakognisi sebesar 46,7 pada model konvensional AB. Rata-rata skor postes keterampilan metakognisi sebesar 76,4 pada model inkuiri terbimbing AA.

Uji normalitas data keterampilan metakognisi diperoleh Sig. (p-level) pada semua kelompok data pretes $(0,71)$ dan postes $(0,86)$ lebih besar dari nilai alpha 0,05 , maka Ho yang menyatakan distribusi data kemampuan metakognisi tidak menyimpang dari distribusi normal diterima. Uji homogenitas dilakukan terhadap data 
post tes keterampilan metakognisi diperoleh Sig. $=0,419$ lebih besar dari 0,05 , maka Ho yang menyatakan varian antar kelompok data kemampuan metakognisi tidak berbeda atau homogen diterima.

Hasil uji anakova keterampilan metakognisi pada sumber model pembelajaran, kemampuan akademik, dan interaksi strategi pembelajaran dengan kemampuan akademik divisualisasikan pada Tabel 3.

Tabel 3.

Hasil Uji Anakova Pengaruh Perlakuan Terhadap

Kemampuan Metakognisi Rubrik

\begin{tabular}{|c|c|c|c|c|c|}
\hline Sumber Variansi & JK & $\mathrm{db}$ & RK & $\mathrm{F}$ & Signifikansi \\
\hline $\begin{array}{l}\text { Model } \\
\text { Terkoreksi }\end{array}$ & $11634.499 a$ & 8 & 1454.312 & 41.688 & .000 \\
\hline Intersep & 15184.054 & 1 & 15184.054 & 435.256 & .000 \\
\hline $\begin{array}{l}\text { Pretes } \\
\text { Metakognisi }\end{array}$ & 377.760 & 1 & 377.760 & 10.829 & .001 \\
\hline Model Belajar & 8376.201 & 3 & 2792.067 & 80.036 & .000 \\
\hline $\begin{array}{l}\text { Kemampuan } \\
\text { Akademik }\end{array}$ & 1239.294 & 1 & 1239.294 & 35.525 & .000 \\
\hline $\begin{array}{l}\text { Model * } \\
\text { Kemampuan }\end{array}$ & 596.587 & 3 & 198.862 & 5.700 & .001 \\
\hline Kesalahan & 4430.436 & 127 & 34.885 & & \\
\hline Total & 573155.495 & 136 & & & \\
\hline $\begin{array}{l}\text { Total Terkoreksi } \\
\text { a. } \mathrm{R} \text { Squared }=, 7\end{array}$ & $\begin{array}{l}16064.935 \\
724 \text { (Adjusted }\end{array}$ & $\begin{array}{l}135 \\
\mathrm{~d} \text { R Sq }\end{array}$ & quared $=, 7$ & & \\
\hline
\end{tabular}

Pada model diperoleh angka sig. $=0,000$ lebih kecil dari alpha $0,05(<0,05)$, maka Ho yang menyatakan tidak ada perbedaan keterampilan metakognisi antara model inkuiri terbimbing, STAD, INSTAD dan konvensional ditolak, sehingga disimpulkan ada pengaruh signifikan model pembelajaran terhadap keterampilan metakognisi. Posisi masing-masing model pembelajaran melalui uji $L S D$ pada taraf sig. $=0,05$ terdapat pada Tabel 4 . 


\section{Tabel 4}

\section{Rata-Rata Skor Keterampilan Metakognisi pada Sumber Model Pembelajaran}

\begin{tabular}{lccclc}
\hline Strategi & XRUB & YRUB & Selisih & RUBCOR & Notasi \\
\hline Konvensional & 24.443 & 52.426 & 27.983 & 52.104 & $\mathrm{a}$ \\
STAD & 20.945 & 60.809 & 39.864 & 61.761 & $\mathrm{~b}$ \\
Inkuiri & 23.530 & 70.515 & 46.985 & 70.526 & \\
terbimbing & & & & & $\mathrm{c}$ \\
INSTAD & 25.315 & 72.257 & 46.942 & 71.617 & $\mathrm{c}$ \\
\hline
\end{tabular}

(Sumber: Lampiran 38)

Uji LSD menunjukkan model INSTAD dan inkuiri terbimbing berbeda nyata dengan model STAD dan konvensional. Model STAD berbeda nyata dengan model konvensional. Model INSTAD dan inkuiri terbimbing mempunyai potensi yang setara dalam meningkatkan keterampilan metakognisi. Model INSTAD dan inkuiri terbimbing lebih berpotensi meningkatkan keterampilan metakognisi dibandingkan model STAD dan konvensional. Model STAD lebih berpotensi meningkatkan keterampilan metakognisi dibandingkan model konvensional. Bila dinyatakan dalam persentase rata-rata skor terkoreksi model INSTAD 37,45\% lebih tinggi dibandingkan model konvensional. Rata-rata skor terkoreksi model inkuiri terbimbing 35,34\% lebih tinggi dibandingkan model konvensional. Rata-rata skor terkoreksi model STAD 18,54\% lebih tinggi dibandingkan model konvensional.

Model INSTAD memiliki karakter inkuiri terbimbing dan STAD. Keterampilan metakognisi pada model INSTAD dilatihkan melalui dua jalan. Jalan pertama melalui karakter inkuiri terbimbing. Karakter inkuiri terbimbing pada model INSTAD melatihkan keterampilan metakognisi melalui kegiatan pemecahan masalah dan aktivitas kerja ilmiah. Kebiasaan siswa mencari solusi terhadap masalah terbukti mampu melatihkan keterampilan metakognisi. Kebiasaan siswa melakukan aktivitas kerja ilmiah menyebabkan terbentuknya kemampuan mengelola diri pada siswa. Jalan kedua melalui karakter STAD. model STAD mendorong setiap anggota 
kelompok menyadari tentang pentingnya belajar dan saling membelajarkan. Kesadaran siswa tentang pentingnya belajar dan saling membelajarkan menyebabkan terbentuknya keterampilan metakognisi. Pelatihan metakognisi melalui dua jalan menyebabkan model INSTAD lebih unggul dalam meningkatkan keterampilan metakognisi dibandingkan model inkuiri terbimbing, konvensional, dan STAD.

Model inkuiri terbimbing diterapkan dalam kelompok tradisional. Kegiatan diskusi, proses berpikir, dan penilaian terhadap tingkah laku juga terjadi pada strategi inkuiri terbimbing yang diterapkan dalam kelompok tradisional, walaupun tidak seefektif pada model INSTAD. Kegiatan diskusi dan pemberdayaan berpikir pada strategi inkuiri terbimbing yang diterapkan dalam kelompok tradisional diduga menyebabkan tidak adanya perbedaan keterampilan metakognisi yang signifikan antara model inkuiri terbimbing dan INSTAD.

Uji hipotesis pada kemampuan akademik diperoleh angka sig. $=0,000$ lebih kecil dari alpha 0,05, maka Ho yang menyatakan tidak ada perbedaan keterampilan metakognisi pada siswa kemampuan $\mathrm{AA}$ dan $\mathrm{AB}$ ditolak. sehingga disimpulkan ada pengaruh kemampuan akademik terhadap keterampilan metakognisi. Hasil analisis pengaruh kemampuan akademik pada Tabel 5.

\section{Tabel 5}

Rata-Rata Skor Terkoreksi Metakognisi yang pada Sumber Kemampuan Akademik

\begin{tabular}{lcccc}
\hline $\begin{array}{c}\text { Kemampuan } \\
\text { Akademik }\end{array}$ & XRUB & YRUB & Selisih & RUBCOR \\
\hline Bawah & 21.728 & 60.084 & 38.356 & 60.751 \\
Atas & 25.389 & 67.920 & 42.531 & 67.253 \\
\hline
\end{tabular}

Tabel 5 menunjukkan siswa kemampuan AA berbeda nyata dengan kemampuan AB. Kemampuan AA lebih berpotensi meningkatkan keterampilan metakognisi dibandingkan kemampuan AB. Kemampuan AA memiliki keterampilan metakognisi 10,70\% lebih unggul dibandingkan kemampuan AB. Isaacson dan Fujita (2006) 
menyatakan, terdapat hubungan antara keterampilan metakognisi dengan keberhasilan akademik. Keterampilan metakognisi dapat digunakan untuk memprediksi keberhasilan akademik siswa. Siswa yang memiliki keterampilan metakognisi tinggi berpotensi lebih berhasil secara akademik dibandingkan siswa yang memiliki keterampilan metakognisi rendah. Penelitian oleh Jamaludin (2009) dan Winarni (2006) menunjukkan, siswa berkemampuan AA memiliki keberhasilan akademik lebih unggul dibandingkan siswa berkemampuan AB. Merujuk pendapat Isaacson dan Fujita (2006) disimpulkan, siswa berkemampuan AA berpotensi memiliki keterampilan metakognisi lebih unggul dibandingkan siswa berkemampuan $\mathrm{AB}$.

Keunggulan siswa berkemampuan AA dibandingkan siswa berkemampuan $\mathrm{AB}$ dalam mengembangkan keterampilan metakognisi diperkuat oleh beberapa penelitian. Penelitian Berkowitz (2005) menunjukkan, penggunaan strategi membaca metakognitif pada siswa berkemampuan akademik AA dengan siswa berkemampuan AB menunjukkan hasil yang berbeda. Siswa berkemampuan AA lebih mampu mengembangkan keterampilan metakognisi dibandingkan siswa berkemampuan AB. Penelitian Jamaludin (2009) terhadap penggunaan strategi PBMP, NHT, gabungan (PBMP-NHT), dan konvensional menunjukkan, siswa berkemampuan AA memiliki keterampilan metakognisi lebih unggul dibandingkan siswa berkemampuan $\mathrm{AB}$.

Persentase selisih pergeseran rata-rata skor keterampilan metakognisi dari pretes ke postes menunjukkan keterampilan metakognisi kemampuan $\mathrm{AB}$ meningkat 177\%, sedangkan kemampuan AA meningkat 168\%. Temuan ini mengindikasikan keterampilan metakognisi siswa kemampuan $\mathrm{AB}$ lebih terangkat dibandingkan siswa kemampuan AA. Fakta ini mengindikasikan, proses scaffolding melalui tutorial oleh siswa berkemampuan AA yang telah menguasai keterampilan metakognisi kepada siswa berkemampuan $\mathrm{AB}$ yang belum menguasai keterampilan metakognisi telah terjadi, akibatnya siswa berkemampuan $\mathrm{AB}$ mampu memasuki zona perkembangan proksimalnya, melampaui zona perkembangan proksimal yang telah dicapai oleh siswa berkemampuan AA. 
Interaksi model pembelajaran dengan kemampuan akademik diperoleh angka sig. $=0,001$ lebih kecil dari alpha 0,05 $(<0,05)$, maka Ho yang menyatakan, tidak ada perbedaan interaksi model pembelajaran dengan kemampuan akademik terhadap keterampilan metakognisi ditolak, sehingga disimpulkan ada pengaruh interaksi model pembelajaran dengan kemampuan akademik terhadap keterampilan metakognisi. Posisi masing-masing kombinasi model pembelajaran dengan kemampuan akademik diungkap menggunakan uji LSD dengan taraf signifikansi 0,05 terdapat pada Tabel 6.

\section{Tabel 6 \\ Uji LSD Interaksi Model Pembelajaran dengan Kemampuan Akademik}

\begin{tabular}{llllllll}
\hline Strategi & Mampu & XRUB & YRUB & Selisih & RUBCOR & \multicolumn{2}{l}{ Notasi } \\
\hline Konvensional & Bawah & 23.781 & 46.744 & 22.963 & 46.663 & a & \\
Konvensional & Atas & 25.105 & 58.109 & 33.004 & 57.546 & b \\
STAD & Bawah & 18.550 & 59.433 & 40.883 & 61.257 & b c \\
STAD & Atas & 23.341 & 62.186 & 38.845 & 62.265 & $\mathrm{c}$ \\
Inkuiri & Bawah & 21.492 & 64.622 & 43.130 & 65.374 & $\mathrm{c} \mathrm{d}$ \\
terbimbing & & & & & & \\
INSTAD & Bawah & 23.088 & 69.537 & 46.449 & 69.708 & $\mathrm{~d} \mathrm{e}$ \\
INSTAD & Atas & 27.543 & 74.977 & 47.434 & 73.526 & $\mathrm{e} \mathrm{f}$ \\
Inkuiri & Atas & 25.568 & 76.409 & 50.841 & 75.677 & & $\mathrm{f}$ \\
terbimbing & & & & & & & \\
\hline
\end{tabular}

Uji LSD menunjukkan, model inkuiri terbimbing AA berbeda nyata dengan model INSTAD AB, inkuiri terbimbing AA, STAD AA dan $\mathrm{AB}$, konvensional $\mathrm{AA}$ dan $\mathrm{AB}$. Model inkuiri terbimbing $\mathrm{AA}$ tidak berbeda nyata dengan INSTAD AA. Model INSTAD AA berbeda nyata dengan strategi inkuiri terbimbing $\mathrm{AB}$, STAD AA dan AB, konvensional AA dan AB. Model INSTAD AA tidak berbeda nyata dengan INSTAD AB. INSTAD AB berbeda nyata dengan model STAD $\mathrm{AA}$ dan $\mathrm{AB}$, konvensional $\mathrm{AA}$ dan $\mathrm{AB}$. INSTAD $\mathrm{AB}$ tidak berbeda nyata dengan inkuiri terbimbing $\mathrm{AB}$. Model inkuiri terbimbing $\mathrm{AB}$ berbeda nyata dengan STAD AA dan AB, konvensional $A A$ dan $A B$. 
Model STAD AA berbeda nyata dengan model konvensional AA dan AB. Model STAD AA tidak berbeda nyata dengan model STAD AB. Model STAD AB berbeda nyata dengan konvensional AB. Model STAD AB tidak berbeda nyata dengan model konvensional AA.

Model inkuiri terbimbing AA dan INSTAD AA mempunyai potensi yang setara dalam meningkatkan keterampilan metakognisi lebih berpotensi dibandingkan dengan model inkuiri terbimbing $\mathrm{AB}$, STAD AA dan AB, konvensional AA dan AB. Model INSTAD $\mathrm{AA}$ dan $\mathrm{AB}$ mempunyai potensi yang setara dalam meningkatkan keterampilan metakognisi. Model INSTAD AB lebih berpotensi meningkat keterampilan metakognisi dibandingkan STAD AA dan AB, konvensional AA dan AB. Model INSTAD AB dan inkuiri terbimbing $\mathrm{AB}$ mempunyai potensi yang setara dalam meningkatkan keterampilan metakognisi. Model STAD AA lebih berpotensi meningkatkan keterampilan metakognisi dibandingkan model konvensional AA dan AB. Model STAD AA dan AB mempunyai potensi yang setara dalam meningkatkan keterampilan metakognisi. Model STAD AB lebih berpotensi meningkatkan keterampilan metakognisi dibandingkan model konvensional AB. Model STAD AB dan konvensional AA mempunyai potensi yang setara dalam meningkatkan keterampilan metakognisi.

Persentase selisih rata-rata skor terkoreksi keterampilan metakognisi pada model inkuiri terbimbing $\mathrm{AA}$ dan $\mathrm{AB}$ sebesar 15,76\%. Persentase selisih rata-rata skor terkoreksi keterampilan metakognisi pada model STAD AA dan AB sebesar 1,65\%. Persentase selisih rata-rata skor terkoreksi kemampuan metakognisi pada model INSTAD AA dan AB sebesar 5,48\%. Persentase selisih rata-rata skor terkoreksi keterampilan metakognisi pada model konvensional AA dan AB sebesar 23,32\%. Temuan ini mengindikasikan, model INSTAD dan STAD dapat membantu siswa kemampuan AB mensejajarkan diri dengan siswa kemampuan AA dibandingkan model inkuiri terbimbing dan konvensional terhadap keterampilan metakognisi.

Bila ditinjau dari selisih persentase rata-rata skor terkoreksi pada kelompok kombinasi strategi pembelajaran dengan kemampuan AA diketahui, model inkuiri terbimbing AA mempunyai kemampuan metakognisi 31,51\% lebih tinggi dari model konvensional AA. Model 
INSTAD AA mempunyai keterampilan metakognisi 27,77\% lebih tinggi dari model konvensional AA. Model STAD AA mempunyai keterampilan metakognisi 8,20\% lebih tinggi dari model konvensional AA. Selisih persentase rata-rata skor terkoreksi pada kemampuan $\mathrm{AB}$ sebagai berikut, model INSTAD AB mempunyai keterampilan metakognisi 49,39\% lebih tinggi dari model konvensional AB. Model inkuiri terbimbing $\mathrm{AB}$ mempunyai keterampilan metakognisi 32,51\% lebih tinggi dari model konvensional AB. Model STAD AB mempunyai keterampilan metakognisi $25,36 \%$ lebih tinggi dari konvensional $\mathrm{AB}$. Hal ini mengindikasikan, kemampuan $\mathrm{AB}$ cenderung lebih terangkat keterampilan metakognisinya dibandingkan AA.

Persentase pergeseran rata-rata skor kemampuan metakognisi dari pretes ke postes pada interaksi strategi pembelajaran dengan kemampuan akademik menunjukkan hal-hal berikut. (1) Keterampilan metakognisi pada model inkuiri terbimbing $\mathrm{AB}$ meningkat 201\%, sedangkan pada inkuiri terbimbing AA meningkat 199\%. (2) Keterampilan metakognisi pada STAD AB meningkat $220 \%$, sedangkan pada STAD AA meningkat 166\%. (3) Kemampuan metakognisi pada model INSTAD AB meningkat 201\%, sedangkan pada model INSTAD AA meningkat 172\%. (4) Keterampilan metakognisi pada model konvensional AB meningkat 97\%, sedangkan pada model konvensional AA meningkat 131\%. Temuan ini mengindikasikan, model inkuiri terbimbing, STAD, dan INSTAD mampu mengangkat keterampilan metakognisi yang dimiliki oleh siswa berkemampuan $\mathrm{AB}$, sebaliknya model konvensional kurang mampu mengangkat potensi keterampilan metakognisi yang dimiliki oleh siswa berkemampuan AB.

Interaksi INSTAD dengan kemampuan AA mempunyai posisi setara dengan interaksi model INSTAD dengan kemampuan AB dalam meningkatkan keterampilan metakognisi. Model INSTAD mampu mensejajarkan keterampilan metakognisi pada siswa berkemampuan AA dan AB. Persentase selisih rata-rata skor terkoreksi kemampuan metakognisi pada interaksi INSTAD dengan kemampuan AA dan AB sebesar 5,45\%. Model INSTAD adalah hasil integrasi sintaks inkuiri terbimbing dengan STAD. Model INSTAD memiliki karakter inkuiri terbimbing dan STAD. Karakter inkuiri terbimbing sebagai strategi kognitif mampu melatihkan keterampilan metakognisi dengan 
baik. Livingston (2005) menyatakan, terdapat hubungan antara strategi kognitif dengan kemampuan metakognisi. Model inkuiri terbimbing mampu melatih kemampuan Mengelola diri pada siswa (Peters, 2006). Kemampuan mengelola diri merupakan bagian dari kemampuan metakognisi.

Karakter STAD pada model INSTAD mampu melatihkan keterampilan metakognisi. Keberhasilan karakter STAD pada INSTAD dalam melatihkan keterampilan metakognisi disebabkan oleh aktivitas diskusi dan pelatihan berpikir. Karakter STAD pada model INSTAD terbukti mampu mensejajarkan keterampilan metakognisi pada siswa berkemampuan AA dan AB. Keberhasilan karakter STAD pada model INSTAD dalam mensejajarkan keterampilan metakognisi antara siswa berkemampuan $\mathrm{AA}$ dan $\mathrm{AB}$ disebabkan oleh aktivitas tutorial sebaya.

Model INSTAD memfasilitasi kegiatan saling membelajarkan antar siswa. Siswa berkemampuan AA yang telah menguasai keterampilan metakognisi memberikan scaffolding kepada siswa berkemampuan AB yang belum menguasai keterampilan metakognisi. Scaffolding berpotensi mendorong siswa berkemampuan AB memasuki zona perkembangan proksimalnya. Tutorial sebaya pada model INSTAD memberikan waktu belajar yang mencukupi bagi siswa berkemampuan $\mathrm{AB}$, sehingga mereka mampu mencapai taraf mastery sebagaimana siswa berkemampuan AA.

Interaksi model INSTAD dengan kemampuan AA menduduki posisi tertinggi tidak berbeda nyata dengan interaksi inkuiri terbimbing dengan kemampuan AA, lebih berpotensi dari interaksi STAD dengan kemampuan AA, dan interaksi konvensional dengan kemampuan AA dalam meningkatkan keterampilan metakognisi. Interaksi model INSTAD dengan kemampuan $\mathrm{AB}$ menduduki posisi tertinggi tidak berbeda nyata dengan interaksi inkuiri dengan kemampuan $\mathrm{AB}$, lebih berpotensi dari interaksi STAD dengan kemampuan $\mathrm{AB}$, dan interaksi strategi konvensional dengan kemampuan $\mathrm{AB}$ dalam meningkatkan kemampuan metakognisi.

Model INSTAD lebih unggul dalam meningkatkan keterampilan metakognisi pada siswa berkemampuan AA dan AB dibandingkan model inkuiri terbimbing, STAD dan konvensional. Model INSTAD 
mempunyai dua keunggulan. Keunggulan pertama, Model INSTAD mampu mensejajarkan keterampilan metakognisi antara siswa berkemampuan AA dan AB. Keunggulan tersebut tidak dimiliki oleh inkuiri terbimbing dan konvensional. Keunggulan kedua, model INSTAD mampu meningkatkan keterampilan metakognisi dengan efektif. Keunggulan tersebut tidak dimiliki oleh STAD dan konvensional.

\section{Kesimpulan}

Model pembelajaran berpengaruh terhadap keterampilan metakognisi. Model INSTAD dan inkuiri terbimbing mempunyai posisi setara dalam meningkatkan keterampilan metakognisi, lebih berpotensi dari model STAD dan konvensional. Model STAD lebih berpotensi meningkatkan keterampilan metakognisi dibandingkan model konvensional. Terdapat perbedaan keterampilan metakognisi antara siswa berkemampuan AA dan AB. Siswa berkemampuan AA memiliki keterampilan metakognisi lebih tinggi dari siswa berkemampuan AB. Ada pengaruh interaksi model pembelajaran dengan kemampuan akademik terhadap keterampilan metakognisi. Model STAD AA mempunyai potensi setara dengan STAD AB. Inkuiri terbimbing AA lebih berpotensi dibandingkan inkuiri terbimbing AB. Model INSTAD AA mempunyai potensi setara dengan model INSTAD AB. Model Konvensional AA lebih berpotensi dibandingkan konvensional AB. Model STAD dan INSTAD berpotensi mensejajarkan keterampilan metakognisi pada kemampuan AA dan $\mathrm{AB}$ dibandingkan model konvensional dan inkuiri terbimbing. 


\section{Daftar Pustaka}

Berkowitz, E. 2005. Metacognitive Reading Strategies of Gifted High Achieving and Gifted Underachieving Urban Adolescent Students. American Educational Research Association Conference, Montreal, Canada 11 April.

Cao, L \& Nietfeld, J.L. 2007. "College Students Metacognitive Awareness of Difficulties in Learning The Class Content does not Automatically Lead to Adjustment of Study Strategy". Australian Journal of Educational and Development Psychology, Vol. 7: 31-46.

Corebima, A.D. 2007. Review On: Learning Strategies having Bigger Potency to Empower Thinking Skill and Concept Gaining of Lower Academic Students. Proceedings of The Redesigning Pedagogy: Culture, Knowledge, and Understanding, Singapore, 28-30 Mei.

Corebima, A.D. 2009. Pengalaman Berupaya menjadi Guru Profesional. Pidato Pengukuhan Guru Besar dalam Bidang Genetika pada Fakultas Matematika dan Ilmu Pengetahuan Alam Universitas Negeri Malang, Malang, 30 Juli.

Coutinho, S.A. 2007. "The Relationship between Goals, Metacognition, and Academic Success". Educate, 7 (1): 39-47.

Desoete, A. 2001. Off-Line Metacognition in Children with Mathematics Learning Disabilities, (Online), (http://archive. ugent.be/retrieve/917/ 801001505476.pdf, diakses 5 Februari 2009)

Drew, C., Hardman, M, \& Hosp, J.L. 2008. Designing and Conducting Research in Education. London: Sage Publication.

Eggen, P.D \& Kauchak. 1996. Strategies for Teachers. Boston: Ellyn and Bacon.

Imel, S. 2002. Metacognitive Skill for Adult Learning. ERICEducational Resources Information Center Trends and Issues Alert No. 39, (Online), http://www.cete.org/acve/docs/tia000107.pdf, diakses 5 Februari 2009) 
Isaacson, R.M \& Fujita, F. 2006. "Metacognitive Knowledge Monitoring and Self-Regulated Learning: Academic Success and Reflections on Learning". Journal of The Scholarship of Teaching and Learning, 6 (1): 39-55.

Jamaludin. 2008. Pengaruh Pembelajaran Pemberdayaan Berpikir melalui Pertanyaan Dipadukan Strategi Kooperatif dan Kemampuan Akademik terhadap Keterampilan Metakognitif, Berpikir Kreatif, Pemahaman konsep IPA-Biologi, dan Retensi siswa SD di Mataram. Disertasi tidak diterbitkan. Malang: Universitas Negeri Malang.

Livingston, J.A. 1997. Metacognition: an Overview, (Online), (http:// www.gse.buffalo.edu/fas/shuell/cep564/Metacog.htm, diakses 5 Januari 2009)

Mcleod, W.B \& Syer, K.D. 2004. Beyond Achievement Data Assessing Changes in Metacognition and Strategic Learning. Canada: Social Sciences and Humanities Research Council of Canada.

Moore, K. 2004. Constructivism \& Metacognition, (Online), (http:// www.tier1. performance.com /Articles/constructivism. PDF, diakses 5 Februari 2009)

Nasution. 2000. Berbagai Pendekatan dalam Proses Belajar Mengajar. Jakarta: Bumi Aksara.

Nurmaliah. 2009. Keterampilan Berpikir Kritis, Metakognisi, dan Hasil Belajar Biologi Siswa SMP Negeri di Kota Malang. Disertasi tidak diterbitkan. Malang: Universitas Negeri Malang

Oussena, S \&Laurie, B. 2007. Assessing Academic Achievement and Acquisition of Expertise in an Agile Development Environment. IADIS International Conference on Cognition and Exploratory Learning in Digital Age, United Kingdom.

Oussena, S \&Laurie, B. 2007. Assessing Academic Achievement and Acquisition of Expertise in an Agile Development Environment. IADIS International Conference on Cognition and Exploratory Learning in Digital Age, United Kingdom.

Ozden, M. 2008. "Improving Science and Technology Education 
Achievement using Mastery Learning Model". World Applied Sciences Journal, 5 (1): 62-67.

Paidi. 2008. Pengembangan Perangkat Pembelajaran Biologi yang Mengimplementasikan PBL dan Strategi Metakognisi, serta Efektifitasnya terhadap Kemampuan Metakognitif, Pemecahan Masalah, dan Penguasaan Konsep Biologi Siswa SMA di Sleman Yogyakarta. Disertasi tidak diterbitkan. Malang: Universitas Negeri Malang.

Petters, E. 2006. "Connecting Inquiry to The Nature of Science as a Metacognitive Resource”. Science Education, 10 (5): 101-104.

Prayitno, B.A. 2010b. Potensi Pembelajaran Biologi Inkuiri dipadu Kooperatif dalam Pemberdayaan Berpikir dan Keterampilan Proses Sains pada Siswa Akademik Bawah. Makalah disajikan dalam Seminar Nasional Optimalisasi Sains untuk Memberdayakan Manusia, Program Studi Pendidikan Sains PPS Unesa, Surabaya, 16 Januari.

Slavin, R.E. 2005. Cooperative Learning: Theory, Research, and Practice. London: Allen and Bacon.

Suratno, 2010. Pengaruh Strategi Kooperatif Jigsaw dan Reciprocal Teaching terhadap Keterampilan Metakognisi dan Hasil Belajar Kognitif Biologi Siswa SMA Berkemampuan Atas dan Bawah. Disertasi tidak diterbitkan. Malang: Universitas Negeri Malang.

Susantini, E. 2004. Memperbaiki Kualitas Proses Belajar Genetika melalui Strategi Metakognitif dan Pembelajaran Kooperatif pada Siswa SMU. Disertasi tidak diterbitkan. Malang: Universitas Negeri Malang.

Susilo, H. 2009. Upaya Membelajarkan Guru IPA/Biologi Masa Depan yang Cerdas dan Profesional. Pidato Pengukuhan Guru Besar dalam Bidang Pendidikan Biologi pada Fakultas Matematika dan Ilmu Pengetahuan Alam Universitas Negeri Malang, Malang, 30 Juli.

Winarni, E.W. 2006. Pengaruh Strategi Pembelajaran terhadap Pemahaman Konsep IPA-Biologi, Kemampuan Berpikir 
Kritis, dan Sikap Ilmiah Siswa Kelas V SD dengan Tingkat Kemampuan Akademik Berbeda di Kota Bengkulu. Disertasi tidak diterbitkan. Malang: Universitas Negeri Malang. 